\title{
Commentary: Shall we stop looking for the lord of the ring?
}

\author{
Michele Di Mauro, MD, PhD, ${ }^{\mathrm{a}}$ Massimiliano Foschi, MD, ${ }^{\mathrm{a}}$ Fabrizio Tancredi, MD, ${ }^{\mathrm{a}}$ \\ Roberto Lorusso, $\mathrm{MD}, \mathrm{PhD},{ }^{\mathrm{b}}$ and Antonio M. Calafiore, $\mathrm{MD}^{\mathrm{c}}$
}

\author{
From the ${ }^{\mathrm{a} D e p}$ artment of Heart Disease, SS Annunziata Hospital, Chieti, Italy; ${ }^{\mathrm{b}}$ Cardio-Thoracic Surgery \\ Department, Heart \& Vascular Centre, Maastricht University Medical Centre, Maastricht, The Netherlands; \\ and ${ }^{\mathrm{c}}$ Department of Cardiac Surgery, Pope John Paul II Foundation, Campobasso, Italy. \\ Disclosures: Authors have nothing to disclose with regard to commercial support. \\ Received for publication Jan 13, 2019; accepted for publication Jan 14, 2019; available ahead of print Feb 14, \\ 2019. \\ Address for reprints: Michele Di Mauro, MD, PhD, Heart Disease Department, SS Annunziata Hospital, Chieti, \\ Via dei Vestini, 66100, Chieti, Italy (E-mail: mdimauro1973@gmail.com). \\ J Thorac Cardiovasc Surg 2019;158:1071-2 \\ $0022-5223 / \$ 36.00$ \\ Copyright (C) 2019 by The American Association for Thoracic Surgery \\ https://doi.org/10.1016/j.jtcvs.2019.01.044
}

Ischemic functional mitral regurgitation (MR) is not a mitral valve disease; rather, it is a pathology of the left ventricle (LV). It is well established that if on the one hand we have morphologic functional modifications of the mitral annulus, such as septal lateral dilatation, reduced circumferential contraction, and reduced intercommissural folding, on the other, there is a significant increase of the tethering forces on the mitral valve leaflets, which show a restrictive motion. ${ }^{1-4}$

As stated by Bothe and coworkers ${ }^{5}$ in their article in this issue of the Journal, even implanting a specifically designed ring cannot have any influence on either papillary muscle position or geometric remodeling of the LV chamber. In fact, even in the presence of improving LV overload, the fate of the LV is more likely determined by other factors, such as increased myocardial perfusion and modification in terms of myocardial tissue (entity of scar and viable myocardium).

In 2009, our group ${ }^{6}$ reported an experience with patients with ischemic MR, with the same nonspecific band used in all cases, showing good echocardiographic results not only in terms of MR recurrence and mitral valve modification but also with respect to LV remodeling. This result was due to the adoption of an echocardiographically based strategy with a consequent decisional algorithm in which we adopt in some case LV surgical reshaping, chordal cutting, and left atrial augmentation in addition to mitral valve annuloplasty.

The strength of this animal study by Bothe and coworkers ${ }^{5}$ is the demonstration that the effort to design and produce specifically designed rings probably goes in a wrong direction, because it is not based on pathophysiology but rather on a merely anatomic principle and is excessively focused on a single element of a problem that appears more complex, and for a complex problem there cannot be simple solutions. At the bottom line, this is the same conclusion of the Cardiothoracic Surgical Trials Network studies of surgical treatment of both moderate ${ }^{7}$ and severe ${ }^{8}$ ischemic MR. ring.

\section{References} 373:1382-94

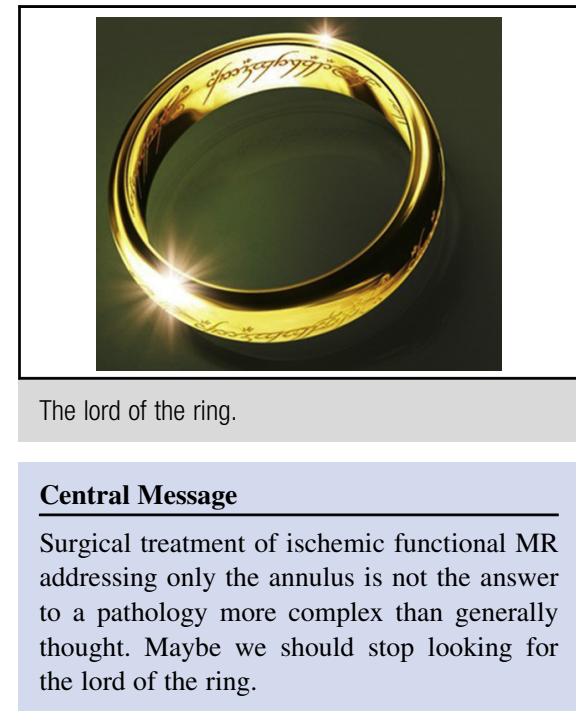

See Article page 1058 .

These studies showed that annuloplasty alone was not enough to correct ischemic MR at 2 years in one-third of the cases $^{7}$ and in two-thirds of the cases, ${ }^{8}$ respectively. Valvular (patch augmentation) or subvalvular surgery (second-order chordal cutting, repositioning of the papillary muscles) must be added to obtain a more stable result. Bothe and colleagues ${ }^{5}$ have demonstrated again, if it was necessary, that addressing only the annulus is not the proper answer to a pathology that is more complex than generally thought. So maybe we should stop looking for the lord of the

1. Perrault LP, Moskowitz AJ, Kron IL, Acker MA, Miller MA, Horvath KA, et al Optimal surgical management of severe ischemic mitral regurgitation: to repair or to replace? J Thorac Cardiovasc Surg. 2012;143:1396-403.

2. Enriquez-Sarano M, Akins CW, Vahanian A. Mitral regurgitation. Lancet. 2009;

3. Timek TA, Miller DC. Another multidisciplinary look at ischemic mitral regurgitation. Semin Thor Cardiovasc Surg. 2011;23:220-31.

4. Silbiger JJ. Anatomy, mechanics, and pathophysiology of the mitral annulus. Am Heart J. 2012;164:163-76.

5. Bothe W, Kvitting J-PE, Rausch MK, Timek TM, Swanson JC, Liang DH, et al. Do annuloplasty rings designed to treat ischemic/functional mitral regurgitation alter left-ventricular dimensions in the acutely ischemic ovine heart? J Thorac Cardiovasc Surg. 2019;158:1058-68.

6. Calafiore AM, Iacò AL, Bivona A, Varone E, Scandura S, Greco P, et al. Echocardiographically based treatment of chronic ischemic mitral regurgitation. J Thorac Cardiovasc Surg. 2011;141:1150-6.e1. 
7. Michler RE, Smith PK, Parides MK, Ailawadi G, Thourani V, Moskowitz AJ, et al; CTSN. Two-year outcomes of surgical treatment of moderate ischemic mitral regurgitation. $N$ Engl J Med. 2016;374:1932-41.
8. Goldstein D, Moskowitz AJ, Gelijns AC, Ailawadi G, Parides MK, Perrault LP, et al; CTSN. Two-year outcomes of surgical treatment of severe ischemic mitral regurgitation. N Engl J Med. 2016;374:344-53. 